\title{
PROSPEK PENGELOLAAN DANA FILANTROPI MELALUI BAITUL MAAL KAMPUS IKOPIN
}

\author{
Nurjamil $^{1} \&$ Siti Nurhayati ${ }^{2}$ \\ ${ }^{1}$ Program Studi Manajemen IKOPIN \\ ${ }^{2}$ Program Studi Ekonomi Syariah IKOPIN \\ Email : nurjamil@ikopin.ac.id, sitinurhayati@ikopin.ac.id
}

\begin{abstract}
ABSTRAK
Penelitian ini dilakukan untuk mengkaji prospek pengelolaan dana filantropi melalui Baitul Maal Kampus IKOPIN dengan terlebih dahulu menggambarkan peta potensi dana filantropi yang dapat digali baik dari dana zakat, infaq, shadaqah maupun wakaf yang bersumber dari seluruh elemen pegawai IKOPIN. Metode penelitian yang digunakan adalah deskriprif kuantitatif dan metode non experiment yakni metode deskriptif dengan teknik survey dalam rangka mengumpulkan data sebanyak-banyaknya melalui kuesioner yang disebar kepada 143 orang pegawai IKOPIN. Penelitian ini menyimpulkan bahwa dana filantropi yang dapat digali dan dikelola di lingkungan Kampus IKOPIN dapat dikatakan cukup potensial, dari 143 responden $67 \%$ responden memiliki kebiasaan untuk mengeluarkan zakat, infaq, shadaqah dan wakaf. Sebanyak $83 \%$ mempunyai pemahaman yang baik mengenai dana filantropi. Berdasarkan data sekunder yang didapatkan dari 86 pegawai Kampus IKOPIN pada lingkup pekerjaan Tenaga Edukatif Tetap, DPK dan Tenaga Administrasi Tetap 76,7 \% memiliki penghasilan di atas batas nishab zakat. Preferensi masyarakat Kampus IKOPIN, sebanyak 87 orang atau 60,8\% responden menyatakan setuju apabila didirikan Baitul Maal Kampus IKOPIN dan 103 orang atau $72 \%$ responden menyatakan bersedia menyalurkan dana filantropi mereka melalui Baitul Maal Kampus IKOPIN sehingga pengelolaan dana filantropi melalui Baitul Maal di Kampus IKOPIN dapat dikatakan cukup prospektif.
\end{abstract}

Kata kunci : Dana Filantropi, Zakat, Infaq, Shadaqah, Wakaf, Baitul Maal Kampus IKOPIN.

\begin{abstract}
This study was carried out in order to investigate the prospect of managing philanthropyy funds via Baitul Maal Campus IKOPIN, describing first of all a map of potential philanthropyy funds which can be excavated from all IKOPIN staff. The research method used is a quantitative descriptive and nonexperimental method, which is a descriptive method with a survey technique to collect as many data as possible through questionnaires distributed to 143 IKOPIN employees. The research concluded that the Philanthropy Fund, which can be excavated and controlled in the IKOPIN campus environment, can be said to have a very high potential, out of 143 respondents $67 \%$ have a habit of issuing zakat Infaq Sadaqah and Waqf. At least $83 \%$ has a good understanding of the philanthropic funds. On the basis of secondary data obtained from 86 IKOPIN employees on the scope of fixed education work, DPK and permanent administrative staff have an income of 76,7\% above the DPK limit. IKOPIN Community preference, as many as 87 people or $60.8 \%$ of respondents indicated that they agree if the establishment of Baitu Maal IKOPIN and 103 people or $72 \%$ said they were willing to channel their philanthropic funds through Baitul Maal IKOPIN to manage the philanthropic funds through Baitul Maal at IKOPIN, so that, the management of funds through Baitul Maal on the IKOPIN Campus can be said to be quite prospective.
\end{abstract}

Keywords : Filanthropy Funds, Zakah, Infaq, Sadaqah, Waqf, Baitul Maal IKOPIN Campus. 


\section{PENDAHULUAN}

Kajian terdahulu mengenai konsep Baitul Maal telah dibuat oleh Hamid (2018). Baitul Maal merupakan institusi khusus yang menangani harta yang diterima negara dan mengalokasikannya bagi kaum muslimin yang berhak menerimanya, dengan arti lain, Baitul Maal adalah tempat penampungan dan pengeluaran harta, yang merupakan bagian dari pendapatan negara. Baitul Maal sebagai tempat penyimpanan harta yang masuk dan pengelolaan harta yang keluar. Beberapa instrumen yang bisa digunakan sebagai pembiayaan publik dan merupakan peran Baitul Maal adalah zakat, asset dan perusahaan negara, kharaj, jizyah, dan wakaf. Penelitian lain dibuat oleh (Wardani \& Tho'in, 2013) yang menyimpulkan bahwa pada saat Umar bin Khatab menjadi khalifah setelah wafatnya $\mathrm{Abu}$ Bakar, kekayaan atau perbendaharaan milik negara di Baitul Maal meningkat sangat signifikan, karena banyak aliran dana dari negara-negara yang ditaklukkan seperti Kisra dan Qaishar. Pada saat Khalifah Usman bin Affan, kekayaan negara lebih melimpah jika dibandingkan dengan dua Khalifah sebelumnya, dimana daerah tersebut lebih banyak ditaklukkan sehingga kas negara semakin banyak, sehingga negara semakin kuat dan sejahtera, bahkan Baitul Maal ketika pemerintahannya mampu membiayai angkatan laut yang menguasai Laut Mediterania. Khalifah Ali bin Abi Talib menganggarkan dana yang digunakan untuk membantu umat Islam yang membutuhkan bantuan, bahkan ia tidak ingin mengambil uang dari Baitul Maal selama perselisihan antara dirinya dan Muawiyah.

Pada dasarnya dalam Islam dikenal dua sistem distribusi kekayaan utama. Pertama, yaitu distribusi komersial dan mengikuti mekanisme pasar melalui kegiatan ekonomi dan kedua distribusi yang bertumpu pada aspek keadilan sosial masyarakat melalui konsep zakat, infaq, shadaqah, harta warisan dan wakaf sebagai dana sosial keagamaan (Amalia, 2009). Sebagai negara dengan jumlah penduduk beragama Islam terbesar di dunia, Indonesia memiliki potensi dana sosial keagamaan (filantropi) yang cukup besar.

Berdasarkan data Badan Amil Zakat Nasional (BAZNAS) potensi zakat nasional dapat mencapai Rp. 252 Triliun, dimana BAZNAS baru dapat menggali sekitar Rp. 8,1 triliun dari potensi yang ada. Selain zakat, Indonesia juga memiliki potensi wakaf yang sangat besar. Badan Wakaf Indonesia mengungkap bahwa Tanah wakaf di Indonesia baik yang sudah bersertifikat wakaf maupun belum bersertifikat mencapai 268.653,67 hektar yang tersebar di 366.595 lokasi di seluruh Indonesia. Potensi tanah wakaf yang dapat digali nilainya mencapai Rp. 2,000 triliun. Sementara potensi wakaf tunai jumlahnya mencapai Rp. 180 triliun, meskipun nilai yang baru dapat digali hanya sekitar Rp. 400 miliar. Potensi yang demikian besar apabila dikelola secara poduktif dapat mendorong percepatan dan perluasan pembangunan ekonomi Indonesia (Direktorat Pemberdayaan Wakaf Departemen Agama RI, 2006). Begitu besarnya potensi wakaf sebagai salah satu sumber dana sosial keagamaan, pada Rencana Pembangunan Jangka Menengah (RPJMN) 2020-2024 pemerintah menaruh perhatian besar terhadap pengembangan sektor ekonomi syariah yang salah satunya adalah mendorong perbaikan dan transparansi, akuntabilitas, kepemilikan, dan profesionalisme dalam pengelolaan dana sosial keagamaan dan mengoptimalkan pemanfaatannya bagi pelaksanaan pembangunan (Menteri Perencanaan Pembangunan Nasional/Kepala Badan Perencanaan Pembagunan Nasional, 2019).

Salah satu potensi ekonomi dana filantropi yang belum tergali secara 
maksimal adalah filantropi masyarakat di lingkungan pendidikan. Berdasarkan data yang dirilis oleh DIKTI, jumlah perguruan tinggi di Indonesia pada tahun 2020 dikerucutkan menjadi 2500 buah. Sementara jumlah dosen secara keseluruhan tercatat berjumlah 247.157 orang dimana pada tahun 2018 yang lalu $20,12 \%$ dosennya telah bergelar doktor. Berdasarkan data tersebut dapat dikatakan bahwa potensi dana filantropi pada lingkungan pendidikan tinggi sangat besar. Keberadaan sebuah lembaga profesional yang mampu menggali dan memaksimalkan potensi tersebut menjadi sangat penting. Peran yang demikian strategis tersebut pada umumnya dilakukan dengan konsep pengelolaan Baitul Maal di Kampus.

IKOPIN merupakan salah satu kampus yang cukup terkemuka di Jawa Barat dengan kekhususan bidang ilmu manajemen koperasi. IKOPIN yang diawali dengan beridirinya Akademi Koperasi (AKOP) pada tahun 1964 dan berubah menjadi IKOPIN pada tahun 1982. Saat ini IKOPIN memiliki 59 Dosen tetap dan 3 orang dosen DPK LLDIKTI serta 5 orang guru besar yang mengajar pada beberapa program studi sesuai dengan bidang keahlian, seperti Manajemen, Akuntansi, Ekonomi Syariah, Jenjang D3 dan Magister Manajemen. Selain itu proses pembelajaran di IKOPIN juga didukung oleh 30 orang tenaga administrasi tetap, 25 orang tenaga administrasi kontrak dan 27 tenaga harian dan cleaning service. Mahasiswa IKOPIN yang tercatat aktif saat ini berjumlah 2789 orang, sebagian besar merupakan mahasiswa dengan latar belakang keluarga ekonomi menengah ke bawah. Dari jumlah tersebut, 298 mahasiswa di antaranya mendapatkan beasiswa yang disediakan baik oleh beberapa Pemerintah Daerah ataupun lembaga lain seperti Bank Indonesia atau program beasiswa lainnya dari BUMN maupun perusahaan swasta, sementara sebagian besar lainnya belum mendapatkan fasilitas beasiswa. Pada keadaan tertentu dana filantropi juga dapat digunakan untuk memberdayakan masyarakat sekitar IKOPIN yang memenuhi kualifikasi sebagai mustahik, sehingga nilai-nilai kekeluargaan di antara masyarakat IKOPIN dapat terbangun lebih erat.

Kajian mengenai prospek
pengelolaan dana flantropi pada
lingkungan kampus IKOPIN merupakan
satu hal yang sangat penting sebagai
rekomendasi pendirian Baitul Maal di
kampus IKOPIN.

\section{TINJAUAN PUSTAKA}

\section{Filantropi Islam}

Dalam bangunan ekonomi Islam sebagai suatu cabang ilmu pengetahuan yang berupaya untuk memandang, menganalisis, dan akhirnya menyelesaikan permasalahan-permasalahan ekonomi dengan cara-cara yang Islami, yaitu caracara yang didasarkan atas ajaran agama Islam, yaitu Al-Quran dan Sunnah (P3EIUII, 2008) dikenal beberapa bentuk kedermawanan yang disebut dengan filantropi. Secara estimologi, makna filantropi (philantropy) adalah kedermawanan, murah hati, atau sumbangan sosial; sesuatu yang menunjukkan cinta kepada manusia (Achols \& Shadily, 1984). Menurut Chaidier S. Bamualim dan Irfan Abubakar sebagaimana dikutip oleh (Nasrullah, 2015) Istilah ini berasal dari bahasa Yunani, yaitu philos (cinta) dan antrhopos (manusia), yang secara harfiah bermakna sebagai konseptualisasi dari praktek member (giving), pelayanan (service) dan asosiasi (association) dengan sukarela untuk membantu pihak lain yang membutuhkan sebagai apresiasi cinta (Bamualim \& Abubakar, 2005). Filantropi di dalam Islam didasarkan kepada dalildalil atau sumber-sumber hukum Islam, yaitu zakat, infaq, shadaqah dan wakaf 
(selanjutnya ditulis ZISWAF) yang dapat diuraikan sebagai berikut (Linge, 2017):

\section{Zakat}

Secara harfiah zakat berarti keberkatan, penyucian, peningkatan dan suburnya perbuatan baik (Usman, 2019). Disebut zakat karena dia memberkahi kekayaan yang dizakatkan dan melindunginya. Di dalam syariah, zakat merupakan suatu kewajiban mengenai sejumlah materi (bahan pokok, uang, mapun bentuk lain seperti binatang ternak) yang dibayarkan atas hal dan tujuan tertentu (jiwa dan harta), ketegori, kadar, waktu dan penerima (mustahik) serta cara yang telah ditentukan oleh hukum Islam (Supriyatni dan Adil, 2018). Menurut M.A. Mannan Zakat secara bahasa artinya yag mensucikan dan yang menumpuk (Mannan, 1992).

Zakat dibagi menjadi dua, yakni zakat jiwa (fithrah) yakni zakat atas jiwa seseorang yang beragama Islam yang hidup sampai dengan malam Idul Fitri (1 syawal) dengan mengeluarkan kurma atau gandum sebanyak satu sha' (H.R. Bukhari-Muslim) atau makanan pokok sebagaimana pendapat jumhur ulama atau dapat diganti dengan uang sebagaimana dibolehkan dalam pendapat Imam Abu Hanifah. Kedua yaitu zakat harta (maal) yaitu zakat atas harta tertentu seperti emas dan perak, perdagangan, pertanian, peternakan, barang yang ditemukan (luqathah), dan profesi atau zakat penghasilan.

Dalam istilah fikih, pendapatan/penghasilan professional mirip dengan maal mustafad yang dijelaskan dalam kitab-kitab fikih zakat. Zakat profesi ini bukan bahasan baru, karena para ulama fikih telah menjelaskannya dalam kitab-kitab klasik, diantaranya kitab al-Muhalla (Ibnu Hazm), al-Mughni (Ibnu Quddamah), Nail al-Athar (Asy-Syaukani), Subul As-Salam (Ash-Shan'ani). Menurut pandangan para ulama tersebut mereka, setiap upah/gaji yang didapatkan dari pekerjaan itu wajib zakat (wajib ditunaikan zakatnya). Diantara para ulama yang mewajibkan zakat profesi adalah Ibnu Abbas, Ibnu Mas'ud, Mu'awiah, ash-Shadiq, al-Baqir, an-Nashir, Daud, Umar bin Abdul Aziz, al-Hasan, az-Zuhri, dan al-Auza'i (Sahroni, 2018).

Zakat profesi itu wajib ditunaikan berdasarkan ayat, maqashid dan maslahat. Diantara ayat yang mewajibkan zakat bersifat umum, seperti firman Allah SWT yang artinya: "Ambillah dari sebagian harta orang kaya sebagai sedekah (zakat), yang dapat membersihkan harta mereka dan mensucikan jiwa mereka, dan doakanlah mereka karena sesungguhnya doamu dapat memberi ketenangan bagi mereka. Dan Allah maha mendengar lagi maha mengetahui". (QS. At-Taubah: 103). Hal ini sesuai dengan maqashid (tujuan) diberlakukannya zakat yaitu semangat berbagi, memenuhi hajat dhuafa dan kebutuhan dakwah. Pendapatan kaum profesional itu besar, harus terdistribusi kepada kaum dhuafa sehingga ikut memenuhi hajat mereka.

Zakat berbeda dengan konsep filantropi yang lain karena selain hukumnya wajib (fardhu), pihak yang berhak menerima zakat (mustahik) juga sudah ditentukan oleh syariat. Adapun pihak yang berhak menerima zakat (mustahik) berdasarkan Al-Quran Surah At-taubah ayat 60 adalah: fakir, miskin, pengelola zakat ('amilin), yang dilunakkan hatinya (muallaf), hamba sahaya, orangorang yang berhutang (gharimin), yang hidup di jalan Allah (sabilillah), dan orang-orang yang safar (bepergian) kehabisan bekal (ibnu sabil).

Khusus untuk zakat atas hata (zakat maal), memiliki beberapa ketentuan atau syarat sebagai berikut: Harta dimiliki secara sempurna, sudah mencapai nishab (ketentuan batas minimal 
harta terkena zakat), dan khusus untuk zakat perdagangan kepemilikan harta tersebut sudah mencapai haul (1 tahun pembukuan)

Nishab zakat atau jumlah minimal harta yang dikenakan zakat berbeda-beda nilainya, hal tersebut didasarkan pada jenis zakat yang ditetapkan. Sebagai contoh zakat penghasilan, maka kadar zakat yang ditetapkan adalah 2,5\%. Nishab zakat penghasilan ditetapkan sebesar 85 gram emas. Apabila 1 (satu) gram emas harganya Rp. 550.000, maka nishab zakat penghasilan adalah $\mathrm{Rp}$. 46,750.000 per tahun. Artinya apabila seseorang mempunyai penghasilan bersih selama satu tahun senilai Rp. 46,750.000 atau Rp. 3.895.000 per bulan, maka ia telah dikategorikan sebagai subjek zakat (muzakki).

\section{Infaq dan Shadaqah}

Konsep lain dalam filantrofi Islam adalah infaq dan shadaqah. Infaq merupakan bentuk kedermawanan yang dianjurkan di dalam Islam yang identik dengan sesuatu yang bernilai materi (dapat diuangkan) sebagaimana termaktub dalam Q.S Al-Baqarah ayat 3 "Artinya : orang-orang beriman kepada yang ghaib, mendirikan shalat dan menginfakkan sebagian rezeki yang telah kami anugerahkan kepada mereka". Sementara itu shadaqah merupakan pemberian yang lebih umum yang dapat mencakup nilai materi (infaq) atau immateri seperti tersenyum kepada saudara sebagaimana dinyatakan dalam Hadits yang diriwayatkan Imam Tirmidzi, Rasululah SAW bersabda "senyum manismu terhadap saudaramu adalah shadaqah" (H.R. Tirmidzi).

\section{Wakaf}

Kata "wakaf" adalah mashdar (kata dasar) dari kalimat waqafa-yaqifuwaqfan". Dalam bahasa arab kata "waqafa" maksudnya adalah berhenti dari berjalan. (Muhammad Bin Shalih Al-
Utsaimin, 2009) Secara etimologi, wakaf adalah al-habs (menahan) sedangkan secara terminologi yaitu: "tahbisul ashl wa tasbiilul manfa'ah (menahan suatu barang dan memberikan manfaatnya) (Praja, 1997). Beberapa sinonim kata yang mempunyai makna yang sejalan dengan makna kata wakaf menunjukan bahwa pengertian wakaf secara bahasa yang berarti: "menahan". Pengertian wakaf secara istilah dapat ditemukan dalam berbagai sumber, terutama dalam kitabkitab fiqih karya para ulama yang populer dalam bidang ijtihad sebagai salah satu sumber hukum Islam.

Berdasarkan Pasal 1 angka (1) Undang-Undang Wakaf, wakaf adalah "Perbuatan hukum wakif untuk memisahkan dan/atau menyerahkan sebagian harta miliknya untuk selamanya atau untuk jangka waktu tertentu sesuai dengan kepentingannya atau untuk keperluan ibadah untuk kepentingan ibadah dan/atau kesejahteraan umum menurut syariah" Dalam istilah yang sudah lazim, wakaf di identikan dengan shadaqah jariyah karena wakaf merupakan bentuk sedekah yang dapat menghasilkan pahala yang terus mengalir (Praja, 1997) bandingkan dengan (Khoerudin, 2018).

Menurut Ismail Nawawi wakaf dapat dibagi menjadi tiga yaitu (Nawawi, 2012) : 1). Wakaf langsung, yaitu wakaf yang memberi pelayanan langsung untuk orang-orang yang berhak, seperti sekolah, masjid, dan rumah sakit, 2). Wakaf produktif, yaitu wakaf harta yang digunakan untuk kepentingan produksi, yang manfaatnya bukan kepada benda wakaf secara langsung, tetapi dari keuntungan bersih hasil pengembangan wakaf yang diberikan kepada orang-orang yang berhak sesuai tujuan wakaf, 3). Wakaf tunai, yaitu wakaf yang berupa uang. Pada masa kejayaan Islam, wakaf uang dimanfaatkan untuk dua tujuan. Pertama, untuk dipinjamkan kepada 
orang-orang yang membutuhkan dan setelah terpenuhi kebutuhannya maka uang tersebut dikembalikan lagi untuk dipinjamkan kepada orang lain tanpa mengambil keuntungan apapun dari peminjam. Kedua, wakaf untuk keperluan produktif.

\section{Baitul Maal}

Menurut Said Hisyam sebagaimana dikutip oleh Widiyanto, Baitul Maal berasal dari bahasa Arab AlBait yang berarti "rumah", dan Al-Maal yang berarti "harta". Baitul Maal berarti rumah untuk mengumpulkan atau menyimpan harta. Baitul Maal adalah suatu lembaga atau pihak (al-jihat) yang mempunyai tugas khusus menangani segala harta umat, baik berupa pendapatan maupun pengeluaran negara Baitul Maal dapat juga diartikan secara fisik sebagai tempat (al-makan) untuk menyimpan dan mengelola segala macam harta yang menjadi pendapatan Negara (Widianto bin Mislan Cokro, 2016).

\section{Baitul Maal Kampus}

Baitul Maal sebagaimana diuraikan di atas merupakan sebuah lembaga yang bergerak dalam mengelola dana filantropi Islam yang terdiri dari daa Zakat, Infaq, Shadaqh dan Wakaf. Baitul Maal pada awalnya merupakan bagian dari lembaga resmi negara yang didirikan dalam rangka membangun negara melalui dana sosial yang pada gilirannya bahkan mampu membiayai pembenjaan negara sebagaimana yang terjadi pada masa kekhalifahan Umar bin Abdul Aziz (717$720 \mathrm{H}$ ) walaupun kemudian eksistensi lembaga tersebut semakin memudar seiring dengan runtuhnya kekhalifahan Islam (3 Maret 1924). Dalam perjalanannya konsep Baitul Maal tetap diadopsi dalam bentuk lembaga sosial yang didirikan masyarakat dalam ruang lingkup yang lebih kecil, salah satunya adalah Baitul Maal pada lingkungan kampus yang dikenal dengan Baitul Maal
Kampus. Dalam pengertian yang sederhana Baitul Maal Kampus dapat diartikan sebagai sebuah lembaga yang didirikan untuk menghimpun dana kebajikan atau dana filantropi yang diserap dan disalurkan kepada masyarakat yag ada di lingkungan kampus.

\section{Sumber Dana, Donatur dan Mustahik Baitul Maal Kampus}

Sebagai sebuah lembaga yang bergerak dalam pengumpulan, pengelolaan dan pendistribusian dana. Maka Baitul Maal Kampus memperoleh dana yang bersumber dari:

1) Zakat (Zakat fitrah dan zakat maal, terutama zakat penghasilan);

2) Infaq dan Shadaqah;

3) Wakaf (baik wakaf tanah maupun wakaf uang termasuk wakaf saham);

4) Fidyah (dana yang dikeluarkan sebagai pengganti puasa bagi yang tidak mampu melakukannya);

5) Luqathah (dana atau barang bernilai materi yang ditemukan di tempat umum dengan memenuhi syarat dan ketentuan syariat);

6) Tabarru' (dana yang dihimpun dengan akad menolong orang)

7) Dana Corporate Social Responsibility (CSR) perusahaan yang menjadi stake holder lembaga pendidikan

8) Bahkan dana non-halal (seperti dana idle dalam saldo rekening nasabah pada lembaga keuangan konvensional yang tidak dapat ditarik oleh nasabah setelah rekening tersebut ditutup).

Maka Baitul Maal Kampus memiliki segmen target yang lebih khusus. Dalam hal ini target penyandang dana (muhsinin) atau para donatur (Muzakki, Mushaddiq, Munfiq dan Muwaqif) lebih banyak berasal dari kalangan civitas akademika kampus tersebut, baik itu kalangan dosen, tenaga 
kependidikan, karyawan maupun mahasiswa serta stake holder yang banyak berinteraksi dengan IKOPIN, seperti Koperasi Keluarga Besar IKOPIN dan perusahaan-perusahaan penyedia beasiswa bagi mahasiswa IKOPIN. Demikian sebaliknya penerima manfaat (mustahik, mauquf alaih atau beneficiary) dari dana tersebut juga lebih banyak dari lingkungan kampus, seperti mahasiswa untuk keperluan biaya pendidikan (beasiswa), dana talang keperluan mahasiswa, dosen untuk keperluan riset dan karyawan serta keluarga karyawan baik itu yang masih aktif terlebih lagi yang sudah masuk masa purna bakti dengan kualifikasi tertentu (sehingga layak disebut sebagai mustahik) yang syarat dan ketentuannya ditetapkan oleh Baitul Maal Kampus.

\section{METODE PENELITIAN}

Metode yang digunakan dalam penelitian ini adalah deskriprif kuantitatif dan metode non eksperimen yakni metode deskriptif dengan teknik survey dalam rangka mengumpulkan data sebanyakbanyaknya melalui kuesioner yang disebar kepada 143 orang pegawai IKOPIN yang marupakan populasi sekaligus sampel dalam penelitian ini.

\section{HASIL DAN PEMBAHASAN}

\section{Uji Validitas}

Suatu alat ukur dikatakan valid, jika alat ukur itu mengukur apa yang harus diukur alat itu. Peneliti melakukan pengujian konstruksi mengenai aspekaspek yang diukur kepada ahli, dalam hal ini peneliti meminta bantuan ahli dalam bidang ekonomi Islam pada dosen Universitas Islam Bandung untuk menvalidasi keabsahan atau kesesuaian instrumen dengan subjek yang diteliti. Untuk menguji validitas konstruksi, dapat digunakan pendapat dari ahli (expert judgement) (Sugiyono, 2012). Setelah didapatkan data uji instrumen, peneliti melakukan tabulasi pada tabel Guttman dengan menyusun item menurut ukuran skor jawaban termudah (1) sampai dengan tersulit (0) untuk membandingkan pola ideal dan pola yang didaptkan, hasil tabulasi Guttman terlampir. Karena instrumen dalam penelitian ini menggunakan kuesioner dengan skala Guttman, maka untuk memperoleh tingkat validitas instrumen kuesioner, penulis menggunakan koefisien Reprodusibilitas dan koefisien Skalabilitas. Adapun rumus untuk menghitung koefisien reprodusibilitas dan koefisien skalabilitas menurut Usman Rianse dan Abdi adalah (Abdi, 2008):

\section{Koefisien Reprodusibilitas (Kr)}

Keterangan :

$$
K r=1-\frac{e}{n}
$$

$\mathrm{Kr}=$ Koefisien Reprodusibilitas

$\mathrm{e} \quad=$ Jumlah kesalahan

$\mathrm{n} \quad=$ Jumlah total pilihan jawaban

$=$ Jumlah pertanyaan $(\mathrm{x})$ jumlah responden

Koefisien Skalabilitas (Ks)

$$
K s=1-\frac{e}{c(n-T n)}
$$

$$
\begin{aligned}
& \text { Keterangan } \\
\mathrm{Ks}= & \text { Koefisien Skalabilitas } \\
\mathrm{e}= & \text { Jumlah kesalahan } \\
\mathrm{k}= & \text { Jumlah kesalahan yang } \\
& \text { diharapkan } \\
= & \mathrm{c}(\mathrm{n}-\mathrm{Tn}) \text { dimana } \mathrm{c} \text { adalah } \\
& \text { kemungkinan mendapatkan } \\
& \text { jawaban yang benar. Karena } \\
& \text { jawaban adalah dikotomi, maka } \\
& \mathrm{c}=0,5 \text { juan } \\
= & \text { Jumlah total pilihan jawaban = } \\
& \text { jumlah pertanyaan (x) jumlah } \\
& \text { responden }
\end{aligned}
$$

Tn = Jumlah pilihan jawaban

Peneliti menggunakan aplikasi Microsoft Excel, Libre Office Calc dan Program Analisis Skala Guttman SKALO untuk melaksanakan uji instrumen (hasil perhitungan terlampir), dan didapatkan hasil dari jumlah responden 143 orang 
dengan jumlah potensi salah/error sebesar 2431 dan jumlah error sebesar 352, dengan koefisien reprodusibilitas $(\mathrm{Kr})$ sebesar 0,85 dan koefisien skalabilitas (Ks) sebesar 0,71. Skala yang dimiliki $\mathrm{Kr}$ $>$ 0,90 dianggap baik, karena nilai dari hasil perhitungan $\mathrm{Kr}$ adalah 0,85, maka $\mathrm{Kr}$ untuk hasil uji instrumen ini dianggap hampir memenuhi. Dalam perhitungan Ks, jika nilai Ks > 0,60 maka dianggap baik untuk digunakan dalam penelitian. Karena dalam perhitungan ini menghasilkan nilai 0,71, maka hasil Ks ini baik digunakan untuk penelitian.

\section{Uji Reliabilitas}

Uji reliabilitas digunakan untuk mendapatkan instrumen yang benar sesuai dengan kondisi di lapangan. Instrumen yang reliabel adalah instrumen tersebut cukup baik sehingga mampu mengungkap data yang bisa dipercaya (Arikunto, 1998). Uji reliabilitas pada penelitian ini dilakukan dengan menggunakan teknik KR 20 (Kuder Richardson), adapun rumusnya adalah :

Mencari nilai varians total :

$$
\begin{gathered}
X t^{2}=\sum X_{t}^{2}-\frac{\left(\sum X_{t}\right)^{2}}{n} \\
S_{t}^{2}=\frac{X_{t}^{2}}{n}
\end{gathered}
$$

Kemudian dimasukan kedalam rumus KR20

$$
r i=\frac{k}{(k-1)}\left\{\frac{S_{t}^{2}-\Sigma p i q i}{S t^{2}}\right\}
$$

Keterangan :

$\mathrm{k}=$ Jumlah item dalam instrumen

$\mathrm{Pi} \quad=$ Proporsi banyaknya subjek yang menjawab pada item 1

Qi $\quad=1-\mathrm{Pi}$

$S_{t}^{2} \quad=$ Varians total
Rumus KR 20 digunakan karena skor yang diperoleh adalah skor dikotomi 1 dan 0, adapun tabel hasil uji reliabilitas instrumen dengan teknik KR 20 terlampir. Maka dengan menggunakan aplikasi Microsoft Excel untuk perhitungan uji reliabilitas instrumen dengan teknik KR 20, didapatkan hasil uji reliabilitas sebesar 0,510, kemudian dimasukan kedalam tabel kriteria reliabilitas. Hasil dari perhitungan menunjukan bahwa reliabilitas cukup untuk digunakan dalam penelitian.

Berdasarkan hasil uji validitas dan reliabilitas yang telah dilakukan, menunjukan aspek tentang peta potensi dana filantropi menunjukan nilai dari hasil perhitungan $\mathrm{Kr}$ adalah 0,85, maka $\mathrm{Kr}$ untuk hasil uji instrumen ini dianggap hampir memenuhi dan valid. Sementara dari perhitungan $\mathrm{Ks}$ menghasilkan nilai 0,71, maka hasil Ks ini baik digunakan untuk penelitian dan valid, sedangkan untuk nilai reliabilitasnya mencapai 0,510 , dimana nilai ini termasuk dalam reliabilitas cukup.

Dalam perhitungan hubungan (koefisien korelasi) diantara variabel $\mathrm{X}$ dengan variabel $\mathrm{Y}$, diaman kedua variabel menghasilkan data ordinal, penulis menggunakan uji hubungan antara variabel $\mathrm{X}$ dan variabel $\mathrm{Y}$ dengan rumus Spearmans. Dari hasil perhitungan (hasil perhitungan terlampir), didapatkan hasil perhitungan 0,930, dimana berdasarkan tabel korelasi karya Duwi Priyatno menunjukan korelasi yang sangat kuat, dimana tercipta korelasi positif (semakin tinggi nilai variabel $\mathrm{X}$ maka akan semakin tinggi nilai variabel $\mathrm{Y}$ ), maka dapat disimpulkan bahwa korelasi atau hubungan antara peta potensi dana filantropi, memiliki hubungan yang positif terhadap preferensi masyarakat kampus IKOPIN terhadap Baitul Maal. 


\section{PEMBAHASAN}

\section{Peta Potensi Dana Filantropi Pada Masyarakat Lingkungan Kampus Institut Manajemen Koperasi Indonesia (IKOPIN)}

Dalam sebuah proses elaborasi dengan tujuan mengungkap gambaran utuh sesuatu, telaah mengenai peta potensi menjadi satu langkah awal yang sangat penting. Sudah menjadi prosedur umum, sebelum ditetapkan sebuah kebijakan baik itu yang sifatnya formal maupun non formal, peta potensi selalu dijadikan intrumen yang menjadi salah satu landasannya. Misalnya, pada kebijakan mengenai investasi, maka pemerintah terlebih dahulu melakukan kajian mendalam tentang peta potensi investasi, demikian juga untuk kebijakan yang lainnya.

Kajian mengenai peta potensi tersebut, juga sudah menjadi bagian tidak terpisahkan dalam dunia filantropi. Peta potensi dana filantropi yang dimaksud dalam hal ini adalah kajian mengenai keadaan umum subjek atau sumber dana filantropi yang dapat digali dan dikelola oleh sebuah lembaga, dalam hal ini adalah Baitul Maal IKOPIN. Peta potensi dana filantropi pada masyarakat IKOPIN dapat dilihat melalui tingkat kedermawanan civitas akademika IKOPIN dan besran potensi dana filantropi yang dapat digali dari masyarakat civitas akademika IKOPIN. Dua hal tersebut didasarkan beberapa kriteria sebagai berikut:

1. Tingkat kedermawanan civitas akademika IKOPIN yang datanya diperoleh melalui kuesioner dengan mengajukan pertanyaan sebagai berikut:

a. Apakah saudara membayar zakat penghasilan setiap bulan?

b. Apakah saudara membayar zakat penghasilan tahun? c. Apakah saudara menyalurkan zakat penghasilan melalui lembaga zakat di dekat tempat tinggal saudara?

d. Apakah selain membayar zakat, saudara juga mengeluarkan dana infaq, shadaqah dan wakaf?

e. Apakah anda berinfaq, bershadaqah dan berwakaf lebih dari satu kali dalam satu tahun?

2. Jumlah calon donator yang ada baik itu dari kalangan dosen, tenaga kependidikan maupun karyawan yang didasarkan pada kualifikasi jumlah penghasilan (take home pay) baik yang memenuhi batas minimum penghasilan terkena zakat (nishab) maupun yang berada di bawah batas nishab yang datanya diperoleh dari bagian Sumber Daya Manusia Institut Manajemen Koperasi Indonesia (IKOPIN).

3. Jumlah mahasiswa aktif dan alumni IKOPIN yang datanya diperoleh dari Bagian Kemahasiswaan Institut Manajemen Koperasi Indonesia (IKOPIN).

Berdasarkan penelitian yang telah dilakukan, maka peneliti dapat menggambarkan bahwa peta potensi dana filantropi tersebut sebagai berikut:

1. Tingkat kedermawanan masyarakat IKOPIN berdasarkan kuesioner yang disebar, berdasarkan pada lima pertanyaan yang diajukan diperoleh data bahwa $67 \%$ responden memiliki kebiasaan untuk mengeluarkan zakat, infaq, shadaqah dan wakaf.

2. Sebaran potensi didapatkan dari pertanyaan nomor 1 sampai dengan 10 , yang menggali tentang pendapatan dan pemahaman responden mengenai dana filantropi, hasilnya menunjukan bahwa $83 \%$ responden cukup faham mengenai dana filantropi dan dianggap 
potensial untuk dijadikan sebagai donator dana filantropi.

3. Nishab zakat penghasilan ditetapkan menurut para ulama adalah sebesar 85 gram emas per tahun. Apabila 1 (satu) gram emas harganya Rp. 550.000, maka nishab zakat penghasilan adalah Rp. 46,750.000 per tahun. Artinya apabila seseorang mempunyai penghasilan bersih selama satu tahun senilai Rp. 46,750.000 atau Rp. 3.895.000 per bulan maka orang tersebut dapat dikategorikan muzakki atau wajib zakat. Berdasarkan data yang diperoleh dari Bagian Sumber daya Manusia Institut Manajemen Koperasi Indonesia (IKOPIN), jumlah dosen atau tenaga edukatif tetap dengan penghasilan mencapai nishab zakat adalah 44 orang atau 78,5\% sementara jumlah tenaga kependidikan atau tenaga administrasi tetap yang penghasilannya mencapai nishab zakat adalah 22 orang atau $75,8 \%$. Berdasarkan data tersebut maka 76,7 $\%$ pegawai IKOPIN yang terdiri dari dosen tetap, DPK, admnistrasi tetap penghasilannya mencapai nishab. Apabila tenaga edukatif tetap dan administrasi tetap berkomitmen untuk membayar zakat penghasilan melalui Baitul Maal IKOPIN , maka dana zakat penghasilan yang terkumpul setiap bulan minimal $(2,5 \% \mathrm{X} \mathrm{Rp}$. $3.895 .000 \times 66$ orang muzakki) $=\mathrm{Rp}$. 5.141.400 atau Rp. 61.696.800 dimana angka tersebut dapat lebih besar mengingat penghasilan dosen IKOPIN umumnya jauh di atas batas minimla nishab zakat. Selain itu penghasilan dosen dan karyawan tidak hanya dari gaji bulanan, tetapi juga didapat dari dana hibah penelitian dan komponen lain, seperti kebijakan Tunjangan Hari raya (THR) maupun Gaji ke-13. Dari keseluruhan populasi yaitu 143 orang pegawai IKOPIN $46,15 \%$ penghasilannya memenuhi nishab zakat.

Sebagaimana diuraikan di atas, kewajiban zakat, ditetapkan kepada setiap muslim yang penghasilannya mencapai nishab, sementara itu bagi muslim yang penghasilannya tidak mencapai nishab, maka tidak diwajibkan mengeluarkan zakat penghasilan. Meskipun demikian bagi setiap pegawai IKOPIN baik itu yang penghasilannya mencapai nishab zakat maupun yang tidak, melihat data mengenai tingkat kedermawanan civitas akademika dimana 107 orang responden atau $74 \%$ responden menyatakan tidak hanya membayar zakat, tetapi bahkan lebih dari satu kali mengeluarkan dana filantropi (infaq, shadaqah dan wakaf) maka potensi dana yang terkumpul melalui Baitul Maal IKOPIN dapat lebih besar lagi.

4. Selain bersumber dari tenaga edukatif tetap dan tenaga administrasi tetap, dana filantropi juga dapat digali dari kalangan mahasiswa itu sendiri. Jumlah mahasiswa IKOPIN yang aktif saat ini adalah 2789 orang. Apabila $75 \%$ mahasiswa tersebut dapat ikut berkontribusi dalam program wakaf uang sebanyak Rp. 5,000 setiap bulan, maka maka akan terkumpul Rp. 10.458.750 dana wakaf atau $\mathrm{Rp}$. 125.505.000 setiap tahun.

\section{Preferensi Masyarakat Kampus IKOPIN Terhadap Baitul Maal IKOPIN Sebagai Lembaga Pengelola Dana Filantropi Masyarakat Lingkungan Kampus Institut Koperasi Indonesia (IKOPIN)}

Berdasarkan pertanyaan kuesioner yang didapat dari pertanyaan 11 sampai dengan 17 dimana 7 pertanyaan tersebut merupakan rangkuman mengenai urgensi lembaga pengelola dana filantropi yang akan dikelola oleh Baitul Maal IKOPIN, 
hasilnya didapatkan bahwa sebanyak $69,9 \%$ responden setuju dengan pendirian lembaga dana filantropi. Secara spesifik berdasarkan kuesioner yang telah disebar, khususnya pertanyaan nomor 15 . Apakah saudara setuju apabila didirikan lembaga pengelola dana zakat, infaq, shadaqah dan wakaf di IKOPIN ? Dari jumlah 143 responden, 87 orang atau $60,8 \%$ orang menyatakan setuju apabila didirikan Baitul Maal IKOPIN dan sisanya 56 responden atau 39,2\% responden menjawab tidak (tidak setuju). Sementara pertanyaan nomor 17. Apakah anda bersedia menyalurkan dana zakat, infaq, shadaqah dan wakaf melalui Baitul Maal IKOPIN ? Dari jumlah 143 responden, 103 orang atau $72 \%$ responden menjawab iya (setuju) dan sisanya 43 responden atau 28\% responden menjawab tidak (tidak setuju).

\section{Prospek Pengelolaan Dana Filantropi Masyarakat Kampus Institut Koperasi Indonesia (IKOPIN) Melalui Baitul Maal Kampus}

Berdasarkan peta potensi dana filantropi dan preferensi masyarakat IKOPIN terhadap pendirian Baitul Maal IKOPIN maka Prospek Pengelolaan Dana Filantropi Masyarakat Kampus Institut Koperasi Indonesia (IKOPIN) melalui Baitul Maal Kampus dapat dikatakan sangat prospektif dengan persentase $76,4 \%$ yang didapatkan dari persentase potensi $83 \%$ dan prosentase preferensi $69,9 \%$.

\section{KESIMPULAN}

Dana filantropi yang dapat digali dan dikelola di lingkungan Kampus IKOPIN dapat dikatakan cukup potensial, dari 143 responden $67 \%$ responden memiliki kebiasaan untuk mengeluarkan zakat, infaq, shadaqah dan wakaf. Sebanyak $83 \%$ mempunyai pemahaman yang baik mengenai dana filantropi. Berdasarkan data sekunder yang didapatkan dari 86 pegawai IKOPIN pada lingkup pekerjaan Tenaga Edukatif Tetap, DPK dan Tenaga Administrasi Tetap, 76,7\% memiliki penghasilan di atas batas nishab nishab zakat. Preferensi masyarakat IKOPIN, sebanyak 87 orang atau $60,8 \%$ responden menyatakan setuju apabila didirikan Baitul Maal IKOPIN dan 103 orang atau $72 \%$ responden menyatakan bersedia menyalurkan dana filantropi mereka melalui Baitul Maal IKOPIN sehingga pengelolaan dana filantropi melalui Baitul Maal di Kampus IKOPIN dapat dikatakan cukup prospektif.

\section{DAFTAR PUSTAKA}

Abdi, U. R. dan. 2008. Metode Penelitian Sosial dan Ekonomi. Alfabeta. Bandung.

Achols, John M. dan Shadily, Hassan. 1984. Kamus Inggris Indonesia Cet. XII. Gramedia. Jakarta.

Amalia, E. 2009. Keadilan Ditributif dalam Ekonomi Islam, Penguatan LKM dan UKM di Indonesia. Rajagrapindo Persada. Jakarta.

Arikunto, Suharsimi. 1998. Prosedur Penelitian Suatu Pendekatan Praktek. PT. Rineka Cipta. Jakarta.

Bamualim, Chaider S. dan Abubakar, Irfan. 2005. Revitalisasi Filantropi Islam: Studi Kasus Lembaga Zakat dan Wakaf di Indonesia. Pusat Bahasa dan Budaya, Universitas Islam Negeri Syarif Hidayatullah Jakarta dan Ford Foundation.. Jakarta.

Direktorat Pemberdayaan Wakaf Departemen Agama RI. 2006. Pemberdayaan Wakaf. Jakarta.

Hamid, A. M. 2018. Peran Baitul Mal Dalam Kebijakan Keuangan Publik. ADILLA : Jurnal Ilmiah Ekonomi Syari'ah, 1(01), 96-116.

Khoerudin, A. N. 2018. Tujuan dan Fungsi Wakaf Menurut Para Ulama 
dan Undang-Undang Di Indonesia. Tazkiya: Jurnal Keislaman, Kemasyarakatan Dan Kebudayaan, 19(2), 1-10.

Linge, A. 2017. Filantropi Islam Sebagai Instrumen Keadilan Ekonomi. Jurnal Perspektif Ekonomi Darussalam, 1(1), 154-171.

Mannan, M. 1992. Ekonomi Islam; Teori dan Praktik. Intermasa. Jakarta.

Menteri Perencanaan Pembangunan Nasional/Kepala Badan Perencanaan Pembagunan Nasional. 2019. Indonesia Menuju Pusat Ekonomi dan Keuangan Syariah Dunia, Materi High Level Discussion pada Muktamar IV Ikatan Ahli Ekonomi Islam(IAEI). Jakarta.

Muhammad Bin Shalih Al-Utsaimin, Syaikh. 2009. Panduan Wakaf dan Wasiat Menurut Al-Quran dan alSunnah. Pustaka Imam Syafi'i. Jakarta.

Nasrullah, A. 2015. Pengelolaan Dana Filantropi Untuk Pemberdayaan Pendidikan Anak Dhuafa (Studi Kasus Pada BMH Cabang Malang Jawa Timur). Hunafa: Jurnal Studia Islamika, 12(1), 1-18.

Nawawi, I. 2012. Fikih Muamalah Kontemporer. Ghalia Indah. Bogor.

P3EI-UII. 2008. Ekonomi Islam. Rajagrapindo Perssada. Jakarta.

Praja, J. S. 1997. Perwakafan di Indonesia; Sejarah, Pemikiran, Hukum, dan Perkembangannya. Yayasan Piara. Bandung.

Sahroni, Oni. 2018. Konsultasi Syariah: Hukum Zakat Profesi. dikutip dari : https://republika.co.id/berita/ekonomi /syariahekonomi/18/02/21/p4hf2j416konsultasi-syariah-hukum-zakatprofesi
Sugiyono. 2012. Metode Penelitian Kuantitatif Kualitatif dan $R \& D$. Alfabeta. Bandung.

Supriyatni, Renny dan Adil, U. 2018. Kamus Hukum Perbankan Syariah (1st ed.). Mitra Wacana Media. Bogor.

Usman, S. A. 2019. Strategi Pengelola Zakat Dalam Menggulangi Kemiskinan. Dedikasi: Journal of Community Engagment, 2(3), 89104.

Wardani, H. K., \& Tho'in, M. 2013. Pengelolaan Baitul Maal Dalam Meningkatkan Kesejahteraan Negara. Jurnal Akuntansi Dan Pajak, 14(1), 6-10.

Widianto bin Mislan Cokro, A. G. 2016. BMT Praktek dan Kasus. Rajagrapindo Persada. Jakarta. 